\title{
International Development in the Brazilian Context in the 1950s and 1960s: A postcolonial reading of Guerreiro Ramos
}

\author{
Maria Fernanda Rios Cavalcanti \\ Fundação Getulio Vargas / Escola de Administração de Empresas de SÃo Paulo, Departamento de Administração, SÃo Paulo - SP, Brazil \\ RAFAEL ALCADIPANI \\ Fundação Getulio Vargas / Escola de AdministraçÃo de EMPresas de SÃo PaUlo, Departamento de AdMinistraçÃo, SÃo PaUlo - SP, BRAZIL
}

\begin{abstract}
This article analyzes, from a postcolonial perspective, ideas observed in the work of the Brazilian sociologist Alberto Guerreiro Ramos. To do this, first, we examine the basis of postcolonial theory, especially the general context where it emerged. Then, we examine the historical context of Brazil in the 1950s and 1960s, by discussing works by the author that portrayed the transformations in the country within this period. We devote special attention to his sociological reduction theory, as it shows his concern to discuss both epistemic colonialism and his idea of development. Finally, we compare how the postcolonial approach and Guerreiro Ramos' ideas relate to one of the most widespread theories having the precept of development as its main source of legitimacy: the International Business and Management Studies (IBMS). This analysis demonstrates that epistemic colonialism was among the key issues of Guerreiro Ramos' thought. However, we conclude that, despite the author's merits in having raised an earlier discussion that is congruent with postcolonial concerns, his thought was deeply rooted in a mystified idea of international development, similar to that of IBMS, very criticized by postcolonialism. This article seeks to contribute to the Brazilian critical organization studies, by showing the potential of postcolonial thought to challenge and defamiliarize ethnocentric and universalistic assumptions that have grounded theories and decision making processes in most of the world's societies since World War II.
\end{abstract}

Keywords: Postcolonialism. Discourse. Development. Colonization.

\section{Desenvolvimento Internacional no Contexto Brasileiro nos anos 1950 e 1960: Uma leitura pós-colonial de Guerreiro Ramos}

\section{Resumo}

Este artigo analisa, sob uma perspectiva pós-colonial, ideias observadas na obra do sociólogo brasileiro Alberto Guerreiro Ramos. Para tanto, primeiro, examinamos a base da teoria pós-colonial, especialmente o contexto geral onde surgiu. Em seguida, examinamos o contexto histórico do Brasil nas décadas de 1950 e 1960, discutindo trabalhos do autor que retrataram as transformações no país nesse período. Dedicamos especial atenção à sua teoria da redução sociológica, pois esta mostra sua preocupação em discutir tanto o colonialismo epistêmico como sua noção de desenvolvimento. Finalmente, comparamos como a abordagem pós-colonial e as ideias de Guerreiro Ramos relacionam-se a uma das teorias mais disseminadas que têm o preceito de desenvolvimento como principal fonte de legitimidade: os Estudos Internacionais de Negócios e Gestão (EING). Esta análise demonstra que o colonialismo epistêmico foi uma das questões-chave do pensamento de Guerreiro Ramos. No entanto, conclui-se que, apesar dos méritos do autor em ter levantado uma discussão anterior e congruente com as preocupações pós-coloniais, seu pensamento estava profundamente enraizado em uma ideia mistificada de desenvolvimento internacional, semelhante à do EING, muito criticada pelo pós-colonialismo. Este artigo busca contribuir com os estudos organizacionais críticos brasileiros, demonstrando o potencial do pensamento pós-colonial para desafiar e desfamiliarizar pressupostos etnocêntricos e universalistas que têm embasado teorias e processos de tomada de decisão na maioria das sociedades do mundo desde a Segunda Guerra Mundial.

Palavras-chave: Pós-colonialismo. Discurso. Desenvolvimento. Colonização.

\section{Desarrollo Internacional en el Contexto de Brasil en la década de 1950 y 1960: Una lectura poscolonial de Guerreiro Ramos}

\section{Resumen}

Este estudio analiza, desde una perspectiva poscolonial, las ideas presentes en la obra del sociólogo brasileño Alberto Guerreiro Ramos. Para esto, en primer lugar, analizamos la base de la teoría poscolonial, especialmente el contexto general en el que surgió. A continuación, examinamos el contexto histórico de Brasil en los años 1950 y 1960, analizando las obras por el autor que han retratado las transformaciones en el país dentro de este período. Dedicamos especial atención a su teoría de la reducción sociológica, ya que ella muestra su preocupación con el colonialismo epistémico y expone su precepto de desarrollo. Por último, vamos a comparar cómo las ideas de Guerrero Ramos y del poscolonialismo se refieren a una de las teorías dominantes más prolíficas que han surgido en el mismo período y que tuvo la idea de desarrollo internacional como una importante fuente de legitimidad: el discurso de los Estudios de Administración y Negocios Internacionales. Este análisis muestra que la cuestión del colonialismo epistémico fue una de las cuestiones clave que estimularon el pensamiento de Guerreiro Ramos. Sin embargo, llegamos a la conclusión que a pesar que el autor plantea una discusión coherente con las preocupaciones poscoloniales, el pensamiento de Guerreiro Ramos estaba profundamente arraigada en una idea mistificada de desarrollo internacional, que es muy criticada por el poscolonialismo. Presentado como evidencia de esta conclusión el hecho de que, cuando se analiza desde una perspectiva poscolonial, las ideas de Ramos Guerrero no critican, pero, en cambio, convergen con el discurso difundido en el mismo período por los Estudios Empresariales y Gestión Internacional. Este artículo tiene como objetivo proporcionar una contribución teórica para el campo de los estudios organizacionales críticos brasileños al mostrar el potencial crítico del poscolonialismo y como este puede desafiar y desfamiliarizar conceptos etnocéntricos y universalistas que han impulsado las teorías y los procesos de toma de decisiones en la mayoría de las sociedades del mundo desde Segunda Guerra Mundial.

Palabras Clave: Post-colonialismo; Discurso; Desarrollo; Colonización

Paper submitted on August 11st, 2014 and accepted for publication on January 28th, 2015

DOI: http://dx.doi.org/10.1590/1679-395131550 


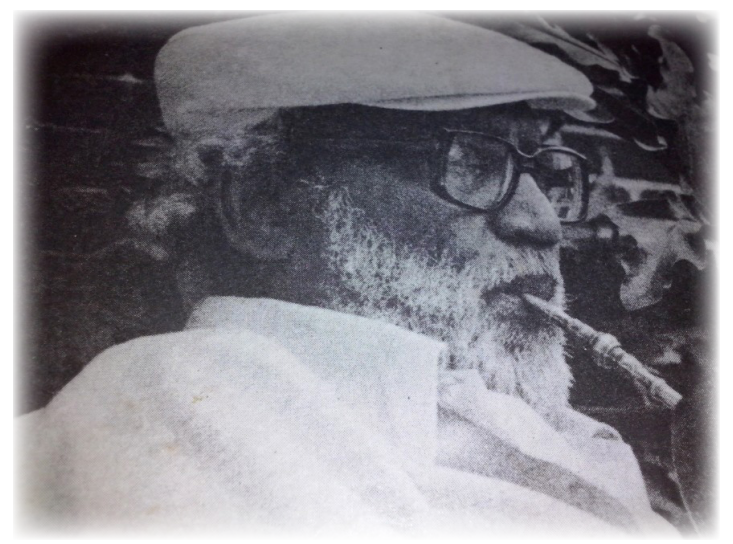

\section{INTRODUCTION}

Guerreiro Ramos was, and still is, one of the most prominent organization studies scholars in Brazil. Should he not be born in Brazil, his ideas would probably have worldwide reach (VENTRISS and CANDLER, 2005). It is clear that the author has contributed greatly to the emergence of the Organization Studies discipline in Brazil. An unquestionable proof of this is the fact that his ideas and concepts raise discussions among Brazilian scholars in this field up to this day. This paper wishes to be part of such discussions, arguing that postcolonial theory may challenge some of the fundamental assumptions contained in Guerreiro Ramos' ideas. As pointed out by Whetten (1989), profound theoretical challenges are part of the development of theories, and they generally precipitate broad reconceptualizations in different disciplines. This paper also wishes to address a possible gap existent in postcolonial theory, that may have failed in emphasizing that it wasn't generated from scratch. Thus it is relevant to analyze if and how a distinguished Latin American theorist such as Guerreiro Ramos may have preceded its ideas (ROSA and ALCADIPANI, 2013).

This paper aims to analyze some of Ramos' most influential ideas from a postcolonial perspective. We depart from the fact that Ramos (1915-1982) was most active in the academia in the 1950 and 1960s decades. Historically this period coincides, on one hand, with the emergence and expansion of the International Business and Management Studies (IBMS) and, on the other hand, with the emergence of the international development discourse. Both discourses were concerned, each with its own peculiarities, with taking "development" to the so called Third World. So called "development policies" legitimated by such discourses have generated vast transformations in most of the world's societies since World War II (FAILLE, 2011). Given such historical context, it does not come as a surprise that the matter of colonialism together with the matter of international development were among some of the key issues that drove Ramos' thought.

Although postcolonial perspective is varied and complex, it has generally denounced epistemology as a mean to subjugate ex-colonies both socially and culturally (CALÁS and SMIRCICH, 1999; PRASAD and PRASAD, 2001). Since the 1950s, management literature has played an important role in the dynamics of epistemological colonialism, especially through the creation and diffusion of the IBMS' discourse (WESTOOD, 2006; WESTWOOD and JACK, 2008). As pointed out by Westwood (2006), IBMS' discourse deploys correlate types of universalistic, essentialising and exoticising representations to colonial and neo-colonial discourse. Also, it has a fundamental connection with the international development discourses vastly disseminated in the 1950s and 1960s. These discourses had the development of the "underdeveloped world" as one of its basic premises (ESCOBAR, 1995).

There is an apparent thematic affinity between postcolonialism and some of Guerreiro Ramos works, indicating that Ramos may have been a precursor to postcolonial thinking. Some of Ramos' most prominent works addressed precisely theoretical and political issues surrounding the dynamics of colonialism and the matter of the development of the

* Fonte da imagem: Alberto Guerreiro Ramos, A Nova Ciência das Organizações: Uma reconceituação da riqueza das Nações. Editora FGV - RJ,1981. 
Brazilian economy in the 1950s and 1960s (RAMOS, 1965). It was mainly through his theory sociological reduction that Ramos addressed both of these issues. Through this theory Ramos analyzed the emergent industrialization of the Brazilian economy and highlighted the importance of developing a critical approach to the importation of foreign thoughts and theories while conducting the development process. Ramos' ideas on colonialism and epistemic subalternity, formulated back in the 1950s, still raise discussions among Brazilian scholars, thus remaining a strong influence in the discipline of Organization Studies in Brazil (see FILGUEIRAS, 2012; PAULA, MARANHÃO, BARRETO et al., 2010; PIZZA-JUNIOR, 2010; BARIANI, 2010; MOTTA, 2010; PAULA, 2007; DAVEL and ALCADIPANI, 2003).

Despite such apparent affinity, while Ramos' influence remains strong in the Brazilian OS field, postcolonial theory was not received with much enthusiasm by scholars. We argue that such disparity contradicts the fact that postcolonialism revives many of the issues addressed by Guerreiro Ramos. In addition, we should consider the fact that the dynamics of colonialism have changed and even became substantially more complex in the last decades. Thus, we shall demonstrate how postcolonialism challenges precedent theories and provides an analytical frame that helps to grasp such complexity. This effort, therefore, will be an attempt to strengthen postcolonialism in Brazil, assuming that this theoretical perspective is especially relevant due to two points: this perspective has had an important role in recovering long silenced voices of those historically marginalized by colonialism and imperialism; postcolonialism has the potential to deconstruct the mystified concepts of development constructed by Western thought that up to this day drive decisions in multiple political and economic spheres in the context of ex-colonies. It's important to highlight that such concepts have remained practically unchallenged over the last decades. Moreover, questioning Guerreiro Ramos ideas can be deployed as manner to give life to a Brazilian postcolonial perspective.

In order to achieve its objective, this paper starts by briefly over viewing the basis of postcolonial theory, especially the general context in which it emerged (marked by the struggle of former colonies against non-traditional forms of colonialism). Afterwards, we examine the historical context of Brazil in the 50s and 60s by discussing some of Ramos' most influential works that accounted for the transformations occurring in the country in that period. We'll give special attention to his theory of sociological reduction for it demonstrates Ramos' concern in discussing both epistemic colonialism and the idea of national development. Finally, we draw a comparison of how both theories criticize (or not) potentially colonialist discourses such as the International Business and Management Studies discourse and the international development discourse.

\section{IMPERIALISM, COLONIALISM AND POSTCOLONIAL THEORY: A BRIEF OVERVIEW}

Since the 1990s, postcolonialism has attracted considerable attention in the field of Organization Studies. This perspective emerged as a theoretical movement that questioned and criticized the colonial condition still existent in the world (YOUNG, 2003). Such emphasis on the critique of colonialism cannot be regarded as something entirely new, given the strong anti-colonial movements that had led to the political independence of European colonies throughout the world. Actually, this perspective's most singular trait was its commitment to subvert the often unquestioned empire of Western categories that have historically subjugated the figure of the Other through various forms (might they be epistemological, cultural, ethical, moral, economical, political, aesthetic, etc.). Given these varied concerns, it comes as no surprise the fact that postcoIonial studies have multiple theoretical frameworks (LOOMBA, 1998; YOUNG, 2001, WESTWOOD, 2006; JACK, SRINIVAS, WESTWOOD et al., 2010). However, it's possible to say that two general intentions underlie this complex theoretical body: first, the wish recover long silenced voices; and, second, its wish to deconstruct essentialist categories and mystified concepts such as the concept of development and ethnocentrism (PRASAD, 1997). In order to reach these aims, postcolonial approaches search for the establishment of a critical epistemological reference bold enough to oppose dominant Western categories that, ultimately, compose the idea of modernity (COSTA, 2006). However, this is a rather recent field of studies and there is no doubt that Guerreiro Ramos' ideas precede most of postcolonial thought in social sciences.

Furthermore, Prasad (2003) explains that postcolonial theory and criticism constitute an attempt to investigate the complex dynamics of Western colonialism. The continuation of the colonial condition after the period of decolonization (ie. the process that led to political independence of almost all European colonies in the world) was made possible by the 
creation of other means to keep ex-colonies socially and culturally subjugated and controlled (PRASAD, 2003). The changes in the dynamics of colonialism made the emergence of postcolonial analysis not only possible, but necessary.

In organizational studies (OS) in general, also according to Prasad (2003), postcolonialism was not received with great enthusiasm and, therefore, this theoretical movement still remains marginalized. This gap is especially worrying to the field of OS in a former colony such as Brazil, where Western colonialism and neo-colonialism have acted as massive forces that undeniable influenced the process of formation and transformation of the Brazilian society. Rosa and Alcadipani (2013) emphasize the fact that Brazil was a colony for more than three centuries. Issues such as social exclusion, extreme poverty, cultural and economical dependences, are only a few of the many social problems that remained despite the political changes achieved after the country's political independency.

The effort of strengthening postcolonialism in Brazil is especially relevant due to this perspective's role in recovering long silenced voices of those historically marginalized by colonialism and imperialism and also due to its potential to deconstruct the myths of international development (PRASAD, 1997). The development myths have been strongly present in Brazil since the 1950s, making this country an ideal terrain for the dissemination of discourses such as IBMS. As highlighted by Faille (2011), the idea of development was a creation of the American and European twentieth century that has remained an almost unchallenged precept over the last decades.

In the next topic we will discuss some of Ramos' ideas produced mainly during 1950s and 1960s. We will also analyze the context of transformations occurring in Brazil during that period - a period of intense societal changes strongly marked by the imperative of development.

\section{GUERREIRO RAMOS' THOUGHT AND THE 1950-1960'S BRAZILIAN CONTEXT}

The purpose of this topic is to overview Ramos' works and to present a brief account of the historical context that provided the background conditions for the emergence of his ideas. Laying out this background will allow us to further analyze how the author accounted for the idea of development and how this precept was present in his works.

The end of World War II, in 1945, drove substantial changes in the international scenario. For Brazil, this was a period of a great increase of North American influence (BARROS and CARRIERI, 2013). It's especially interesting to note that in the 1950s the first wave of foreign capital entered the Brazilian market (RODRIGUES and CARRIERI, 2001), leading to deep societal changes. These changes were analyzed by Guerreiro Ramos, Ramos (1965) affirmed that this moment of transformation was characterized by three phenomena: industrialization, urbanization and changes in popular consumption (when Brazilian citizens were being transformed into consumers).

This period also coincided with the opening of the first management schools in Brazil. These schools provided the first undergraduate courses in business and public administration in the country (BERTERO and KEINERT, 1994). It's important to note that close to all business courses being offered in Brazil by the 1960s had received direct support and funding by the American government - with only two exceptions; one in the state of Minas Gerais and another course in the state of Pernambuco (MACHADO, 1966). This is evidence that the American influence in Brazil was not restricted to the economical and political spheres; it also comprised an ideological sphere through the diffusion of business and management education.

The process of industrialization of the Brazilian economy was, to Guerreiro Ramos, a source of intellectual excitement. The author stated that this moment of transformation demanded the creation of what he called a critical conscious that should lead the process of modernization. The crucial point made by the sociologist was the importance of taking under consideration local particularities and needs while conducting such process (RAMOS, 1965). Guerreiro Ramos was one of the first Brazilian scholars to defend the necessity of formulating local theories in order to make foreign ideas more adequate to local reality, making his ideas at this stage close to postcolonial concerns. However, this scenario of transformations and strong (but rather dubious) foreign influence sparked multiple reactions in Brazil, also fueling streams of nationalism. Ramos was a scholar who, especially in the 1960s, actively participated in the defense of a so called "revolutionary nationalism". The nationalist ideology seen in Ramos writings at that time had as a key premise the questioning of the Brazilian colonial condition (MOTTA, 2010). 
However, Ramos' notion of nationalism was peculiar. The author explained that what he understood as nationalism was precisely the struggle of a nation to free itself from a colonial condition. But he also claimed that the colonial condition was the sole reason for nationalism, adding that once a country reaches its goal of sovereignty and enters the realm of "universality and of civilization" the necessity of nationalism ceases to exist (RAMOS, 1960, p. 225-226). Furthermore, Faria (2009) points out that Ramos called this type of nationalism a "scientific nationalism". This "scientific nationalism" was underlined by a non-xenofobic appropriation of foreign knowledge based on rational principles. To put it in other words, for Ramos, adopting a scientific nationalism was a necessity if Brazil was to reach the goal of development (BRESSER-PEREIRA, 2011).

Ramos' worries surrounding issues associated with the assimilation of foreign ideas and its relation to local peculiarities gave birth to his theory of Sociological Reduction. Sociological Reduction was "the elimination of everything that, for its secondary character, disturbs the process of comprehension and the obtaining of what is essential in a given thing" (RAMOS, 1965, p. 81). Ramos suggested through this theory that any foreign theory or practice can be assimilated or imported, as long as this assimilation is mediated by the local, regional or national context. It's clear that Ramos doesn't stand against the assimilation of foreign knowledge or practices, what he put into question was how this process should be conducted. Therefore, Ramos does not put into question essential traits of such theories or practices (and its universal assumptions and/or categories), on the contrary, he posed as a strong defender of such Western categories when he defended the idea of "scientific nationalism" based on rational principles, which has an Enlightment flavor. The so called critical assimilation of imported knowledge and practices trough sociological reduction was, according to the author's writings, a mandatory process for that period of transformations and was aimed especially to the development of the Brazilian economy. Thus, Ramos' theory of sociological reduction could be seen as a theoretical tool that should be used to achieve national development.

Ramos (1965) classified such transformations (notedly industrialization, urbanization and the emergence of a Brazilian consumer market) as processes of evolution of the Brazilian society. The author was also a defender of urban life that, contrary to rural life, stimulated "individualism, competition, initiative capacity, and the interest in superior patterns of existence" (RAMOS, 1965, p. 74). Ramos (1983) also promoted a normative concept of "good society" that would be inseparable from the strategies of modernization undergoing in that period (RAMOS, 1983). Another trait of Ramos' theory of sociological reduction was its strong criticism of other Brazilian sociologists who, at that time, condemned the industrialization process. The author argued that the claim that Brazil should stay faithful to its "rural vocation" would only serve the interests of dominant nations who would prefer the rest of the world to remain trapped in backwardness.

In addition, it's important to highlight that a crucial trait of the theory of sociological reduction formulated by Ramos was its pragmatic approach. According to Maio and Lopes (2012), Ramos criticized scholars who had a "bookish" attitude, that is, who didn't engage in empirical research. According to the author, only through the analysis of practical local matters "true" and useful local knowledge could be generated. This pragmatic attribute of Ramos theory, added to his clear concern with the nation's development through industrialization, makes it not surprising that throughout his later works Ramos (1981) questioned specific issues related to practical matters of organizations and their functioning in the Brazilian context. Later on, Ramos would extend this analysis to a global level. In such discussions, one of his main concerns was the development of skills that could help private and state companies introduce rationality in their structures while they adapt to local realities.

During his exile in the USA, when he worked as a scholar at the University of South California, Ramos' wrote one of his most influential works, The New Science of Organizations (originally published in English). By reviewing some of his earlier works' ideas, Ramos (1981) explains that his theory of sociological reduction had three main concerns: first, it regarded the process of importation of foreign science and culture (as we have already noted here); secondly, it was concerned with providing individuals with a systematic cultural "training" in order to preserve their "genuine" self; and, finally, this theory proposed the necessity of an abrupt change in the institutional form of social sciences. The New Science of Organizations was, then, a step forward in Guerreiro Ramos' intellectual project. It was an attempt to reformulate the science of organizations in order to reconcile the modernization process with ideals of reason.

Thus, Ramos' book was an attempt to shift the so called modern project away from its negative consequences. In this book, Guerreiro Ramos reported encountering such negative consequences while living in the USA (according to the author, the main ones were the following: psychological insecurity, degradation in quality of life, pollution and excessive 
production of waste). Ramos (RAMOS, 1981) asserted that only a true, rational science could avoid such negative consequences. Here we can see a clear shift from the theorist who once questioned the Brazilian reality to an author that later started to think in terms of the context of central societies. In this book, Ramos no longer makes reference to colonialism and is completely embedded in Western categories.

We should also note that this wasn't the first transformation in Ramos' thought. Smith (2006) points out that, until 1955, Ramos produced many papers on blackness due to his racial background and other reasons. The author states that after 1955, Ramos did not produce more work on this subject, quoting: "In his interview with CEPEDOC in 1981, when asked if the personal problems he had experienced had had relationship with his color, he responded positively saying "Brazil is a country of idiots" (SOARES, 2006, p. 139). Thus, Ramos abandoned the "romantic" character of his work when he put aside questions about blackness in Brazil.

Soares (2006) also states that Ramos began to regard sociology as a science with a strong instrumental character, and for this reason he started studying management as a hard fact and as a social system. The topics covered by Ramos' thereafter included: rationality, ethics, alienation, work, class, power, reason, modernization, among other topics. However, we note that all of these topics were guided by the same ideal of international development, "where administrative action takes maximum scale inspired by the intention of promoting social change" (SOARES, 2006, p. 82). Rios (1983) corroborates this view, highlighting the fact that Ramos' intellectual change was due to the pragmatic form that his sociological project had assumed.

In short, Ramos' works overviewed here first analyzed the societal changes that Brazil was undergoing in the 1950s and 1960s. According to the author's reading, these changes were being driven by three phenomena: industrialization, urbanization and the emergence of a consumer market. Ramos proposed that, under the scrutiny of the sociological reduction, the importation of foreign knowledge and practices would both produce authentic local knowledge and drive Brazil out of its colonial condition and into the realm of "universality and civilization". After his move to the US, Ramos let the issue of colonization and nationalism aside, and proceeded to analyze central societies. Ramos produced trough such analysis strong ideals of man, science and rationality and forged a conception of organization in accordance with the universalized concept of Western reason. Earlier, Ramos had already abandoned his concerns with "national development" and started to express a concern with the matter of "world development". Ramos concluded that world development tended to become the ultimate goal of the scientific community (RAMOS, 1970).

While analyzing possibilities of how such world development could be achieved, Ramos (1970) discussed the need of implementing an "administration of development". In order to discuss this point the author cites Thompson (1964) and shows a clear affinity with the ideas contained in this work. Thompson (1964) basically advocated that, in order to bring development to underdeveloped countries, administrative principles must be applied. However, the author points out that such principles must shift away from control and concentrate around adaptation in order to succeed in peripheral countries. Thus, Ramos (1970) defended not only the idea that an ideal of development should be spread throughout the entire world, but the idea that development should be administrated in a global scale. Through such ideas, it can be said that Ramos could have provided legitimacy for the dissemination of the discourse of international business and management studies.

In the next section we will further examine Ramos' ideas, specifically through a postcolonial perspective, and trace a parallel with the ideas widely disseminated in the 1950's and 1960's by the International Business and Management Studies.

\section{RAMOS THOUGHT VERSUS IBMS DISCOURSE: A POSTCOLONIAL QUESTIONING OF INTERNATIONAL DEVELOPMENT}

In this section we'll proceed with a postcolonial reading of Ramos' thought through the analysis of a possible alignment between Ramos ideas and some of the ideas that underlined the discourse of International Business and Management Studies, especially in the idea of International Development.

As argued in the last topic, Ramos addressed early in his work a certain form of nationalism that underlined many ideas that were generally present in Brazil in the 1950s. However, his concept of nationalism did not incite xenophobia; on the contrary, he defended the importance of importing foreign ideas and practices, as long as they were subjected to a 
critical analysis. As covered previously, Ramos called this analysis sociological reduction and it was a mean of giving foreign ideas pragmatic functionality in the local context. So, to a certain extent, the sociological reduction would be a way of distinguishing which social theories are useful in the national context and which aren't useful (VENTRISS and CANDLER, 2005). Thus, the sociological reduction was an exercise of what Ramos called a "scientific nationalism", a notion based on the ideals of Western reason and centered around the precepts of progress and development. It is noteworthy that such concern with the Brazilian context was not a constant in his thought. Thus, in this topic we shall discuss both the early aspects of his thought, that basically comprised his theory of sociological reduction, as well as his later works, giving emphasis to his publication The New Science of Organizations.

Ramos' theory of sociological reduction is convergent with postcolonialism's concern with imperialism. However, when we take a closer look at it, it becomes clear that the early nationalist trait of Ramos' thought - marked by his defense of the need to develop an authentic sociological discipline in close correspondence with Brazilian particularities - was a partial criticism to imperialism. We assert that the criticism made by Ramos (1957) to imperialism seems consistent only when referring to economic imperialism. In this sense, Postcolonial thought provides a more complete lens to analyze this dynamics, since it doesn't restrict its criticism to economic imperialism. Postcolonialism attempts to criticize, as said before, all forms of imperialism and subjugation, including the idea of development itself, that was never challenged by Ramos, quite the opposite.

According to Sumner (2008), postcolonialism regards the idea of international development as a dominant discourse of Western modernity, particularly triggered in 1949 by a speech of US President Truman, who declared: "we must embark on a bold new program for making the benefits of our scientific advances and industrial progress available for the improvement and growth of underdeveloped areas" (cited in Esteva, 1992, p. 6, APUD Sumner, 2008). Escobar (1995) explains that the organizing premise of the development discourse was the belief that modernization was the only way out of so called "archaic" relations present in the Third World. In order to achieve this, it was "absolutely necessary that government and international organizations take an active role in promoting and orchestrating the necessary efforts to overcome general backwardness and underdevelopment" (ESCOBAR, 1995, p. 86). The International Business and Management Studies discourse emerged during this same period, evidencing the entrance of private organizations in the enterprise of development. In 1954, as highlighted by Robinson (1981), there is record of the first international business course in a major business school in the US. John Mayer-weather taught the course "Managing Foreign Operations" at Harvard. This fact shows evidence that, by this time, there was a general awareness that Business had become a major international actor.

Westwood (2008) explains that the IBMS discourse can be seen as being parallel to the international development discourse. The author highlights that, even though this discourse was created in the US and it was shaped by this country 's own interests, it posed as being superior and universal. It also regarded Third World countries' "development" only as a tool for controlling and better profiting from their markets. According to a postcolonial reading, the figure of the Other, under this logic, is completely subjugated and marginalized. Thus, the underdeveloped world is created in such discourse as inferior and is silenced while being forced to accept the ideals of development and modernization imposed by "superior" actors (PRASAD, 2003).

Postcolonialism denounces the dissemination and imposition of a universalist discourse as a highly colonialist act. Yet, Ramos strongly believed in the universality of sociology as a Science - that for the author should be the same in Germany, England, France or Brazil (MAIO and LOPES, 2012). This reveals an affinity of Ramos' ideas with the discourse of IBMS. Even though Ramos highlighted the importance of taking local context into consideration, the author expressed an ambiguous account of local and marginal knowledge, as he strongly criticized the ramifications of sociological studies in Brazil that would study "distant" subjects/objects. By "distant objects" the author meant objects that were disconnected from the pragmatic goal of national development. Ramos regarded such objects as esthetic issues, providing as examples "missing tribes, the bobbin lace, the struggles of families, communities, assimilation of immigrants [...]" (RAMOS, 1957, p. 27). Ramos thus expressed his desire for universals, applicability and a functional/pragmatic approach to theory. Such desire is inseparable from the development based and pragmatist logic of IBMS, which in turn played an important role in maintaining colonial control in the world ever since its emergence.

This affinity is also present in his interpretations of society in his book New Science of Organizations, for example. Such readings, even though professedly based on his analysis of European and American societies, were regarded by him as 
the result of "a sense of reality common to all individuals, at all times and in all places" (RAMOS, 1981, p. 46). This trait of Ramos' thought also converges with a basic premise of the IBMS discourse, that by presenting itself as universal tends to depreciate other types of knowledge or simply regard them as being outside the realm of Knowledge. The figure of the other is, thus, silenced and excluded by both approaches.

In addition, Ramos' insistence on the necessity of formalism in the search for development also resembles the IBMS discourse. According to Westwood (2006), the IBMS discourse is produced according to U.S. ideologies and, when disseminated, it serves to best transact and control other cultures and societies. Ramos (1983) defended the role of an elite group in disseminating prescribed standards as a basic premise of his notion of formalism. According to this view, mass' conducts are rightfully prescribed and regulated by a formal standard laid out by the elite. Ramos (1983) asserts that "the elite have always more consciousness than the mass of the conventional character of rules and standards, given their privileged participation in the social process" (RAMOS, 1983, p. 255). The fact that the elite detains a form of privileged knowledge of the social systems would, then, legitimate the domination and control of a small and central group over a peripheral one, for example.

We must acknowledge the fact that Ramos criticized functional rationality that dominated organizational studies (WEBERING, 2010). Yet, we assert that the author proposed an alternative to this functional rationality that was, still, an appeal to an ideal of rationality (notably, the substantive rationality proposed by the author).Thus, the author created an ideal rationality that despite being local imposed itself as universal, constituting a dash of colonialist behavior similar to that of IBMS and other colonialist discourses that commonly seek legitimacy by laying universalist assumptions.

It should be noted that in The New Science of Organizations (RAMOS, 1981), written when Ramos was a scholar living in the USA, the author criticized the mechanistic aspects of Taylorism. However, Ramos wasn't critical of Taylor's functional and instrumental rationality (see RAMOS, 1978, p. 553). According to Bariani (2009), when Ramos criticized certain "undesired" aspects of Taylorism, this was evidence that the author no longer saw a convergence between modernization and reason. Yet, the author believed that precisely reason could put modernization "back on track". We must highlight that Ramos was still appealing to an idea of reason as a universal category, a point that is rejected by postcolonial thought. Postcolonialism regards such notion of reason a Western form of domination and subjugation.

Ramos (1983) clearly diverges from such postcolonial view when stating that science should be universalizing and should serve as a mean for driving the development process in peripheral countries: "The sociological reduction does not mean isolationism, nor romantic exaltation of the local, regional or national. It is, instead, directed by a universal aspiration mediated, however, by the local, regional, or national [...]" (RAMOS, 1965, p. 83-84). In short, the objectives of the sociological reduction, can be defined as the following: first, Ramos intended to integrate the sociological discipline in Brazil with the idea that sociology was an universal Science; secondly, the author wished to formulate a methodology for conducting sociological interventions endowed with pragmatic values in order to play a role in the construction of national development. According to a postcolonial view, the sociological reduction could be defined as a critical assimilation of oppressive Western categories by peripheral (and inferior) countries that takes into account their local particularities in order to bring them out of their backwardness and into development. Thus, sociological reduction ultimately served the interests of the IBMS ideology as its goal of development was dependent on the success of foreign organizations in adapting and establishing operations in diverse local realities.

It is also interesting to note with respect to certain forms of nationalism found in Ramos' earlier works that they seem to have been left abandoned as he developed his ideas. The author stated that "the nation, as such, is fast becoming unviable as a unit of analysis" (RAMOS, 1970, p. 28-9) "nowadays a social scientist cannot be nationalistic, for the same reasons why a biologist cannot be racist" (RAMOS, 1970 , p. 29). According to the author, social science should be global. A postcolonial scrutiny would assert that his notion of "global science" and/or "global knowledge" equaled North American and/or European science or knowledge, since he remains faithful to their most basic assumptions and categories, especially their precepts of universal reason, truth, and ethnocentrism. This shift of focus in Ramos' analysis, which moved from the nation level to the global level, is seen by postcolonialism as highly problematic and also ambiguous. That is, even though Ramos had the noble objective of bringing well being to all humanity, the imposition of universal world views opens the door to all forms of domination and subjugation, as denounced by postcolonial thought. Such 
point is corroborated by Mignolo (2006), who asserts that making universal assumptions only serves to segregate and discard knowledge produced outside central countries.

Besides, the author defended the same division between underdeveloped countries and central developed countries (RAMOS, 1983) as the one present in the discourse of international development. To postcolonial thought, such world view ultimately divides the world into "superior and inferior" countries. Ramos seemed to defend this division based on his observations of the American society described in his theoretical works, stating that the U.S. had reached a greater refinement of social dynamics. Given such separation, the author warned that what was considered true about administrative sciences in the U.S. could not be applied to underdeveloped countries such as Brazil.

However, Ramos (1983) states that an "underdeveloped country" should not be doomed to have "an underdeveloped science", re-affirming his conviction in the universality of science that was to be held above local realities. In addition, the author clearly expressed his opinion that the U.S. would be in a "superior" position, and that Brazil would not be in the position to welcome some trends of American sociology and anthropology, for it could not "[...] skip a phase to another that is superior" (RAMOS, 1957, p. 113). Ramos (1965) explains that the fact that he had spoken about the need for a national sociology does not mean that he defended a type of rationality and or an ideal of reason different of those found in Western dominant countries, since "[...] in the general plan of sociological reasoning, 'standards', 'values', 'ideal' transcend historical particularities of each national society" (RAMOS, 1965, p. 32). In his later works, Ramos' declared writing from an American/European perspective, taking such societies as a parameter and referring to the rest of the world as "backward", "underdeveloped", "poor", "wild", "colonized", "alienated", etc.

Moreover, it is interesting to note that while regarding the Brazilian context Ramos (1983) described a typical Brazilian citizen citing a work written by a foreigner. This piece of work cited in Ramos (1983) labeled Brazilians as being a sad, ignorant, fatalistic, passive, and uncritical people when compared to American and/or European citizens. For instance, according to the author, while Brazilians spent money on gambling, Europeans chose a more rational path and invested resources in capitalist savings. As highlighted by Mignolo (2005), negative descriptions of peripheral countries and their people had a very important role in their process of subjugation and inferiorization conducted by central countries. The realization that Ramos (1983) seemed to accept and reproduce such a negative description of Brazilian people is a disconcerting fact.

In addition, Ramos' concept of "emancipated man" or "parenthetical man" can be regarded as a projection of an ideal model of man who poses as universal but who is, in fact, an European/North American/white male. According to Ramos (1972) this man is to prevail in the organizational world and to become a model for the rest of the world. We quote Ramos:

The parenthetical man is both a reflection of, and a reaction to new social circumstances that are more perceptible now in advanced industrial societies like the United States, but which will eventually prevail throughout the entire world (RAMOS, 1972, p. 244).

When describing this precept of "model of man", "found" by the author in industrial/central societies, Ramos seems to contradict what he stated back in 1965 when he said that "American sociology suffers from low technical and scientific level, it tends to confuse the particular dynamics of U.S. society with the general social dynamics" (RAMOS, 1965, p. 136). It seems that mutations in the thought of Guerreiro Ramos, from the Sociological Reduction to the New Science of Organizations, include an adoption of a more ambiguous approach to his former anti-colonial criticism.

In addition - and this is another striking resemblance with the IBMS discourse - Ramos considered the United States to be the "pilot country in the western world" where the "first trends of the future" would appear (RAMOS, 1983, p. 55). Going further, Ramos says its development induces the U.S. to "become promoters of economic and social agencies for conscious and planned development" (RAMOS, 1983, p. 55). Thus, when analyzed from a postcolonial perspective, Ramos' writings not only have certain ideological convergence with IBMS discourse, but they also played an important role in providing a much needed legitimacy for the dissemination of IBMS ideas and, consequently, for the dissemination of foreign enterprises in the so called Third World. One example of why such legitimacy was needed was the growing risks of nationalization of invested capitals through communist revolutions, for example (TRUITT, 1970).

We also conclude that the concerns present in most of Ramos writings analyzed here don't regard the necessity to overcome the colonial logic. Rather, this necessity is suppressed by statements that promote the belief that the so 
called underdeveloped countries could achieve the same level of development as the so called developed countries (might it be intellectual, cultural and/or economic). The most basic colonialist feature of this proposal is to ascribe to Western rationality as a universal category (which must be exported and assimilated by all). Under a postcolonial point of view, such proposal is highly oppressive, since it imposes central countries' values and ideals of progress and development that must be accepted by all other "inferior" countries. Finally, it is noted that Guerreiro Ramos' sociological reduction's goals seem to coincide with the developmentalist goal of the IBMS discourse, which seeks to address local realities for the better functioning of organizations that will supposedly lead such local communities to a promised land of development.

Despite the critique made by Ramos to the colonial situation in his early works, we conclude here that it was restricted to criticizing a certain form of economic domination. While analyzing this the author's writings, we conclude that the thought of Guerreiro Ramos can be perceived as embedded in and as a promoter of a form of ideological or epistemic colonialism. Latin American issues such as the production of local knowledge have been a source of reflection to postcolonial thought since its early days. As already said, this matter was brought up by this perspective due to its view that the dynamics of colonization cannot be restricted to economical and political spheres. In this sense, colonization is seen as a broad process that also relies on the construction of social and cultural subalternity which includes knowledge production and dissemination spheres. Thus, we argue that postcolonialism provides an approach capable of accounting for the matter of today's colonialism in a complex manner required by this dynamic's multiple and obscure facets. We do not aim to diminish Ramos important work, but we want to surface what can be seen as some of his work problematic assumptions.

\section{CONCLUSION}

In this paper we demonstrate how postcolonial theory calls into question fundamental assumptions of Ramos' thinking. Concentrating on the precept of development was a way of illustrating the broadness of postcolonial theory challenges to Ramos' assumptions. We conclude that, when discussed from a postcolonial perspective, Ramos' ideas did not solely criticize but also converged with colonialist discourses, such as the IBMS discourse, strongly disseminated in the 1950s and 1960s. This historical approach was important to our analysis for it made it possible to understand the context where these discourses emerged.

Also, we pointed out that although there were considerable theoretical changes throughout Ramos' work, his incline towards universalist categories and his commitment to Western ideals of progress and development were a constant trait of his works analyzed here.

Besides that, it can be highlighted that even though Ramos clearly problematized colonial issues in his theory of sociological reduction, this criticism was partial, leaving aside other forms of colonization that postcolonialism brings to the fore (such as social subjugation and control). It is also important to note that the objective of Ramos' theory of sociological reduction wasn't to criticize the importation of foreign ideas. Rather, he proposed this theory as a mean to import foreign theories and concepts; he did not criticize Western ideals of development, humanity, truth, and scientific practice, rather these ideals composed the theoretical underpinnings of his thought. Postcolonialism, on the contrary, strongly criticizes such ideals. Postcolonial discourse can be regarded as a counterpoint to such universalistic and ethnocentric discourses that are up to this day active forces in global attempts to transform societies.

Finally, it is important to highlight that this paper does not aim to raise doubts around Guerreiro Ramos unquestionable academic and theoretical contributions to sociology in general and to the field of Organizational Studies in particular. It neither wishes to point flaws in his writings. Quite the opposite, our point was to trace an argument that allowed us to discuss and give life to some of Guerreiro Ramos ideas that are still relevant today. Yet, we argued that a new socio-historical context forces us to question our idea's theoretical contours, or underpinnings, in order to fulfill their critical potential. 


\section{REFERENCES}

BARIANI, E. O Longo Caminho: Guerreiro Ramos e a Sociologia da Administração Antes de A Nova Ciência da Organização. Organização \& Sociedade, v. 17, n. 5, p. 17-28, 2010.

BARROS, A. N.; CARRIERI, A. Ensino superior em Administração entre os anos 1940 e 1950: uma discussão a partir dos acordos de cooperação Brasil-Estados Unidos. Cad. EBAPE.BR, v. 11, n. 2, p. 256-273, 2013.

BERTERO, C. O.; KEINERT, T. M. M. A Evolução da Análise Organizacional no Brasil. Revista de Administração de Empresas, v. 34, n. 3, p. 81-90, 1994.

BRESSER-PEREIRA, L. C. From the National-Bourgeoisie to the Dependency Interpretation of Latin America. Latin American Perspectives, v. 38, n. 3, p. 40-58, 2011.

CALÁS, M. B.; SMIRCICH, L. Pastpostmodernism? Reflections and tentative directions. Academy of Management Review, v. 24, n. 4, p. 649-671, 1999.

COSTA, S. Desprovincializando a sociologia: a contribuição pós-colonial. Revista Brasileira de Ciências Sociais, v. 21, n. 6, p. 22-39, 2006.

DAVEL, E.; ALCADIPANI, R. Estudos Críticos em Administração: A Produção Científica Brasileira nos Anos 1990. Revista de Administração de Empresas, v. 43, n. 4, p. 72-85, 2003.

ESCOBAR, A. Encountering Development: The Making and Unmaking of the Third World. Princeton: Princeton University Press, 1995.

FAILLE, D. D. Discourse analysis in international development studies: Mapping some contemporary contributions. Journal of Multicultural Discourses, v. 6, n. 3, p. 215-235, 2011.

FARIA, J. H. Consciência crítica com ciência idealista: paradoxos da redução sociológica na fenomenologia de Guerreiro Ramos. Cad. EBAPE.BR, v. 7, n. 3, p. 421-446, 2009

FILGUEIRAS, F. B. Guerreiro Ramos, a Redução Sociológica e o Imaginário Pós-Colonial. Caderno CRH, v. 25, n. 65, p. 361-377, 2012.

JACK, G. et al. Call for papers - special issue on interrogating organization through the postcolonial. Organization, v. 16, n. 5, p. 776, 2010.

LOOMBA, A. Colonialism/Postcolonialism. London: Routledge, 1998.

MACHADO, M. O Ensino da Administração Pública no Brasil. Rio de Janeiro: Fundação Getulio Vargas, 1966.

MAIO, M. C.; LOPES, T. C. Da Escola de Chicago ao Nacionaldesenvolvimentismo: Saúde e Nação no pensamento de Alberto Guerreiro Ramos (1940 - 1950). Sociologias, v. 14, n. 30, p. 290329, 2012.

MIGNOLO, W. Os esplendores e as misérias da "ciência": colonialidade, geopolítica do conhecimento e pluriversalidade epistêmica. In: SOUSA SANTOS, B. (Org.). Conhecimento prudente para uma vida decente: um discurso sobre as ciências revisitado. 2. ed. São Paulo: Cortez, 2006.
MIGNOLO, W. The darker side of the Renaissance. Chicago: University of Michigan Press, 2005.

MOTTA, L. E. A Política do Guerreiro: Nacionalismo, revolução e socialismo no debate brasileiro dos anos 1960 . Organização \& Sociedade, v. 17, n. 52, p. 85-101, 2010.

PAULA, A. P. P. Guerreiro Ramos: resgatando o pensamento de um sociólogo crítico das organizações. Organização \& Sociedade, v. 14, n. 40, p. 169-188, 2007.

PAULA, A. P. P. et al. Tradição e a Autonomia dos Estudos Organizacionais Críticos no Brasil. Revista de Administração de Empresas, v. 50, n. 1, p. 10-23, 2010.

PIZZA-JUNIOR, W. Guerreiro Ramos, Administração e Ciências Sociais. Organização \& Sociedade, v. 17, n. 52, p. 201-208, 2010.

PRASAD, A. The Gaze of the Other: Postcolonial Theory and Organizational Analysis. Postcolonial Theory and Organizational Analysis: A Critical Engagement, Nova York: Palgrave, 2003.

PRASAD, A. The Colonising Consciousness and Representations of the Other: a postcolonial critique of the discourse of oil. In: Prasad, P. et al. (Eds.). Managing the Organizational Melting Pot: Dilemmas of Workplace Diversity. London: Sage, 1997. 285-311 p.

PRASAD, A.; PRASAD, P. Otherness at Large: Identity and Difference in the New Globalized Organizational Landscape. In: MILLS, A.; MARJOSA, I. (Eds.). Gender, Identity and Culture of Organizations, London: Routledge, 2001. 57-71 p.

RAMOS, A. G. Introdução Crítica à Sociologia Brasileira. Rio de Janeiro: Editorial Andes Limitada, 1957.

RAMOS, A. G. O problema nacional do Brasil. Rio de Janeiro: Saga, 1960.

RAMOS, A. G. A Redução Sociológica - introdução ao estudo da razão sociológica. 2. ed. Rio de Janeiro: Edições Tempo Brasileiro, 1965.

RAMOS, A. G. A Nova Ignorância e o Futuro da Administração Pública na América Latina. Rev. Adm. Pública, v. 4, n. 2, p. 7-45, 1970.

RAMOS, A. G. Models of Man and Administrative Theory. Public Administration Review, v. 32, n. 3, p. 241-246, 1972.

RAMOS, A. G. Misplacement of Concepts and Administrative Theory. Public Administration Review, v. 38, n. 6, p. 550-557, 1978.

RAMOS, A. G. A Nova Ciência das Organizações - uma reconceituação da riqueza das nações. Rio de Janeiro: Fundação Getulio Vargas, 1981.

RAMOS, A. G. Administração e Contexto Brasileiro. Rio de Janeiro: Fundação Getulio Vargas, 1983.

RAMOS, A. G. Uma Introdução ao Histórico da Organização Racional do Trabalho. Brasília: Editora Pontual, 2009.

RIOS, J. A. Debate à exposição de Ubiratan Simões Rezende. Rev. Adm. Pública, v. 17, n. 2, p. 120-123, 1983.

ROBINSON, R. D. Background Concepts and Philosophy of International Business from World War II to the Present. Journal 
of International Business Studies, v. 12, n. 1, Tenth Anniversary Special Issue, p. 13-21, 1981.

RODRIGUES, S. B.; CARRIERI, A. P. A Tradição Anglo-Saxônica nos Estudos Organizacionais Brasileiros. Revista de Administração Contemporânea, v. 5, n. edição especial, p. 81-102, 2001.

ROSA, A.; ALCADIPANI, R. A Terceira Margem Do Rio Dos Estudos Críticos Sobre Administração E Organizações No Brasil: (Re)Pensando A Crítica A Partir Do Pós-Colonialismo. RAM, Rev. Adm. Mackenzie, v. 14, n. 6, Edição Especial, p. 185-215, 2013.

SANTOS, B. S. Crítica da razão indolente. São Paulo: Cortez, 2003.

SOARES, L. A. A. A Sociologia Crítica de Guerreiro Ramos - um estudo sobre um sociólogo polêmico. Rio de Janeiro: CRA-RJ Publicações, 2006.

SUMNER, A. International Development Studies: Theories and Methods in Research and Practice. Sage Publications, 2008.

THOMPSON, V. A. Administrative Objectives for Development Administration. Administrative Science Quarterly, v. 9, n. 1, p. 91-108, 1964.

TRUITT, J. F. Expropriation of Foreign Investment: Summary of the Post World War II Experience of American and British Investors in the Less Developed Countries. Journal of International Business Studies, v. 1, n. 2, p. 21-34, 1970.
VENTRISS, C.; CANDLER, G. G. Alberto Guerreiro Ramos, 20 Years Later: A New Science Still Unrealized in an Era of Public Cynicism and Theoretical Ambivalence. Public Administration Review, v. 65, n. 3, p. 347-359, 2005.

WEBERING, S. I. Os Pontos Cegos das Teorias Organizacionais Segundo Guerreiro Ramos. Anais do XXXIV Encontro da ANPAD. Rio de Janeiro, 2010.

WESTWOOD, R. International Business and Management Studies as an Orientalist Discourse - a postcolonial critique. Critical Perspectives in International Business, v. 2, n. 2, p. 91-113, 2006.

WESTWOOD, R.; JACK, G. The US commercial-military-political complex and the emergence of international business and management studies. Critical Perspectives on International Business, v. 4, n. 4, p. 367-388, 2008.

WHETTEN, D. A. What Constitutes a Theoretical Contribution? Academy of Management Review, v. 14, n. 4, p. 490-495, 1989.

YOUNG, R. Postcolonialism: An Historical Introduction. Oxford: Blackwell, 2001.

YOUNG, R. J. C. Postcolonialism: a very short introduction. New York: Oxford University Press, 2003.

Maria Fernanda Rios Cavalcanti

PhD. student and Master degree in Business Administration at Getulio Vargas Foundation - São Paulo School of Business Administration (FGV-EAESP). E-mail:mfcavalcanti@gmail.com

Rafael Alcadipani

PhD. in Business Administration at Manchester Business School; Adjunct Professor at Getulio Vargas Foundation - São Paulo School of Business Administration (FGV-EAESP); Visiting researcher at University of Manchester; Visiting Professor at Gothemburg Research Institute. E-mail: rafael. alcadipani@fgv.br 